\title{
The German Peasant War of 1525
}

NOTHING tends more fatally to vitiate our comprehension of a 1 great historical event than to devote all our attention to a single one of its aspects. The great outbreak of the peasantry of southern and central Germany in the year 1525 has had a very considerable amount of attention devoted to it by historians; anfortunately, however, it has won that attention not so much from its own interest, as from the light which it casts on some of the developments of the Reformation. Its religious bearings are discussed with a fulness which leads to a neglect of its equally important social and economical aspects. Some of its most characteristic features are slurred orer because they arose from uninteresting local politics : some of its most unimportant and incidental developments are brought into undue prominence because they can be made to illustrate the great movement of the day. Ont of the whole history of the war historians are prone to fix on two events, Thomas Münzer's fantastic proceedings at Muhlhausen and the massacre of Weinsberg, and to allow their readers to suppose that these were typical instances of the behaviour of the peasants all over the land. But it was precisely on account of their strange and abnormal nature that these two occurrences obtained notice: neither blasphemous fanaticism nor cold-blooded slaughter was a prominent feature in the insurrection. Münzer, however, was Luther's nearest neighbour and antagonist, while the massacre of Weinsberg was the incident which frightened into union all those classes in Germany which had anything to lose, and sent them crusading against a movement with which many of them had previously sympathised. Thus the ravings of the mad prophet and the atrocities of the 'White Band' of Franconia have secured a place in history which their own intrinsic importance did not deserve. On the other hand there are numerous features in the rise and development of the revolt which are usually passed over in unmerited silence. Ulrich of Würtemberg's invasion of Swabia at the head of his Swiss allies-an invasion which exactly synchronised with the crisis of the rebellion-paralysed for the moment the only armed force which could be turned against the insurgents, and was within an ace of securing a triumph for them. Yet how 
little atfention has the exiled duke's bold enterprise attracted : Ranke dismisses it in less than twenty lines, many minor writers do nut mention it at all. It did not fall within the sphere of Luther's action, it did not connect itself with the great movements of the time, and therefore it has been dismissed to oblivion. Nevertheless its influence on the history of the war can hardly be exeiggerated.

Original sources for the history of the peasant war exist in plenty. Its Thuringian episodes have several narrators; its main conrse in Swabia and Franconia many more. A peruasl of those accounts contained in Baumann's invaluable 'Quellen zur Geschichte des Banernkriegs' has led the writer of the present article to endeavour to produce a narrative more consecutive then those with which he is at present acquainted in the English tongue. More especially has he endeavoured to work out, with the aid of several narratives - and above all of that of the writer who dotailed the itinerary of the army of the Swabian league during the insurrection-the military side of the insurrection, the one among its aspects which has been the most commonly neglected.

For some thirty years before the commencement of the Reformation peasent wars had been continually breaking out. When the misery of the people of any district reached an unbearable pitch, a local revolt followed. Since 1490 there had been risings in Elsass, in the Low Countries, at Kempten, at Bruchsasl, in Würtemberg, in Carinthis. In some cases the anger of the insurgents had been directed against priests and monks, in others against feadal superiors, while occasionally a tyrannical prince had provoked the convulsion. But each rebellion had been purely local, and caused by some specific acts of oppression. As yet no national movement had arisen to stir up the whole of the peasantry to one simultaneous outbreak. At last, however, the impulse came, in the shape of the great wave of feeling in favour of a religious reformation which rolled over all Germany from the ocean to the Alps. The same cause which in 1522 had sent forth Sickingen and his knights on their freebooting crusade against the archbishop of Trier, was now to set in motion the villagers of Swabia and the Thüringerwald.

To the pessant latest of all Germans, for he was the most isolated and debased member of the nation, there came an echo of the preaching of Luther. He was told that the oppressive religious system under which he was living was an organised hypocrisy, a mockery and perversion of true Christianity. The luxury and pride of the higher clergy, the ignorance and greed of the lower, were asserted to be God's judgments on the church for going astray from the spirit of the true faith. 'The pope,' cried the preachers of the new doctrines, "is antichrist, and the clergy the servants of antichrist." At the same time a new scheme of salva- 
tion was opened to the peasant, and it was one very different from that which had been expounded to him by his parish priest. With the fervent reassertion of Christ's invitation to the poor and sinful were mixed scathing denunciations of clericel oppressors. Both portions of the message appealed to the peasant, and his soul inclined to the new teaching. But a readiness to listen to the reformers' sermons did not constitute him an idesl Christian. He allowed too much of the gospel teaching concerning love and obedience to paiss over his hesd. But he hearkened to Christ's blessings un the poor till he almost fancied that his own wretched condition was enough to constitute him one of the elect. He had detested his clerical tyrants before, and now he was furnished with religious, as well as temporal, reasons for abhorring them. A onesided reading of his bible was liable to make him look upon them as Pharisees to be cursed, if not as Amalekites to be smitten with the edge of the sword.

The peasent was thus tanght to resist one of his masters; but at this point he did not stop. It is not strange that his ignorance and misery led him to carry the ideas which were brought to him concerning religion into the sphere of social life. The intaition of Luther might perceive that individual liberty was required in spiritual things, but not in temporal ; the pesasnt, however, was not so clearsighted. He could not draw a hard and fast line between obedience to the oppressor of -his soul, and obedience to the oppressor of his body. Indeed, in numberless cases, where a bishop or a monastery was his fendal superior, the persons were the same. There are passages enough in holy writ which speak of all Christians as equal in the sight of God. Men read them and pondered on them, till their own wretchedness began to make them question whether there was a greater obligation to obey evil temporal than evil spiritual ralers. They had been bidden to free themselves from one bondage, and now would they not be justified in freeing themselves from the other? Who were the nobility and the princes, it was asked, that they should make slaves of their Christian fellowmen?

While this was the frame of mind of the peasantry, they fell into the hends of men who were the most eccentric products of the Reformation. The fanatical Karlstadt and the raging madman Münzer had been driven out of Saxony by Lather and the party of order, and now they with their fellows and disciples were wandering up and down the land. Karlstadt, arrayed in the grey frock of a peasant, roamed through southern Germany, preaching of the equality of all Christian men, the vanity of baptism, and the mistaken view taken by the reformers as to the meaning of the Lord's supper. His crowning delight was iconoclasm, and wherever the populace were influenced by him, his sermon was followed by the 
destraction of the sculptares and ornaments of the nearest charch. If Karlstadt did not absolutely inculcate sedition, he certainly conduced to its progress. His violence in enforcing spiritual reform confirmed others in the belief that violence might be employed to obtain social reform also. We shall soon find him in the heart of the Franconian revolt, influencing the burghers of Rothenburg to cast in their lot with the revolted pessantry.

The famous Thomas Münzer was even wilder than Karlstadt. He began by asserting that the Reformation and Chriatian equality might be defended by the sword, but he enderi with the frightfol Taborite doctrine that all opponents not only might, but must, be put to death by ' the saints.' This last development of his theories, however, was not perfected till after the outbreak of the revolt, when his first success had rendered him quite beside himself, and altogether irresponsible for his own actions. For the last two years he had been growing more and more frenzied, and wandered like an unquiet spirit through all the lands between Tharingia and Switzerland. His teaching had considerable effect, though even among the peasants most men shrank as yet from its worst enormities.

There were numerous preachers of less note who were more or less infected with the taint of sedition. All through southern Germany, aqve perhaps in Bavaria, the lower parochial clergy were deeply stirred by the new movement. Not a few among them were maddened by the wrongs of the class from which they had sprung. The priests of Leipheim and Günzberg in Swabia and Strauss of Eisenach were found among the leaders of the rebellion of 1525 , and the first named is said 'by some to have compiled the famous ' Twelve Articles.' It is noticeable that similar defections from the ranks of the church had not been anknown in the earlier peasant wars. Priests had been implicated in the old 'Bundschuh' rising, and in the ' League of Poor Conrad.'

Many of the German towns were drawn into the rebellion of 1525. The causes of their revolt were various. In some cases the town was a small agricultural centre, inhabited by a class in close touch with the peasantry, who felt the ordinary rural grievances as keenly as their neighbours in the open country. In other coses, as at Würzburg, the rising was political, as the townspeople hoped to take advantage of the convulsions of the time, and by liberating themselves from their sovereign to become froe like the imperial cities. In other places, as at Rothenburg, religious differences had embittered the old strife between the oligarchy who formed the town council and their less privileged fellow-citizens. The latter were easily led to call in the insurgent peasantry to aid them in putting down their oppressors. In the small towns of Würtemberg the Austrian governors had set themselves to crush the reforming move- 
ment, and were hated as persecutors as well as foreigners. But, with the single exception of Mühlhausen, the towns were not driven into the war by the religious frenzy which had proved such a powerfal incentive to the raral population.

By the summer of 1524 the times were ripe, and the great outbreak took place. 'In the month of August of the year 1424,' writes one of the contemporary chroniclers of the rebellion, "the peasants of the landgraviate of Stühlingen rose against their lord Count Sigmund of Lüpfen, maintaining that they were overburdened with fendal services, and impoverished by his hunting and preservation of game. When they came together and found no one to withstend them, they grew haughty and highminded, and said that they would no longer be serfs.' 1

It has been affirmed that the immediate cause of the rising was a command of the countess of Lüpfen that the peasants should spend a holiday in collecting snail shells for her. Apparently this display of petty caprice added the last straw to the burden of the discontented villagers. They flocked together in arms to the number of six hundred, whereupon Count Sigmund sought refuge behind the walla of Radolfzell, a small town at the foot of the lake of Constanz, and despatched letters asking for assistance to Archduke Ferdinand of Austria and George Truchsess, general of the forces of the Swabian league.

Meanwhile the numbers of the assembled peasants rapidly increased. They set up a white, red, and black standard-a sign that they disavowed their allegiance to the local sovereign,- - and chose as their leader one Hans Müller, an old lanzknecht. This man, ' an evil and rebellious fellow' as he seemed to his master, was one of the fow chiefs of the revolt who displayed any capacity for organisation or command. When he found himself at the head not only of the Stühlingen people, but also of the subjects of the counts of Sulz and Fürstenberg, he was encouraged to carry out a scheme which had been suggested to him by the fanatic Thomas Münzer. He determined to establish an 'evangelical brotherhood,' whose members should each contribute two kreutzers to a fund destined for the payment of agitators who were to be despatched throughout the land. They were to rouse the peasantry and extend the association over Dwabia and the whole of south Germany. The way for them had already been prepared by Münzer, who had for some time been wandering up and down, preaching his new gospel of reformation by the sword. Ronsed by these missionaries or excited by the impunity of their neighbours, the villagers of the Hegau and Klettgen joined the revolt in October, while in November the people of the parts of the Black Forest round Villingen were added to the rebels.

\footnotetext{
' Schreiber des Truchsessen Georg ton Waldburg, p. „27.
} 
By this time the Archduke Ferdinand and the Swabian league had collected some 2,000 troops, whom they placed ander the command of Jacob von Landau, and sent into the disturbed region. For one moment there was a chance that the movement might be checked without a collision. The peasents did not assume the offensive, while the free action of the soldiery was fettered by the dread of provoking the Helvetic confederates. The Swiss of Schaffhausen owned much property in the Stühlingen territory, and would have resented fiercely any injury which might follow the ravages of open war. The Swabian league had no desire to see a repetition of the conflict of 1499 , when it had fared so badly at the hands of its southern neighbours. Accordingly negotiations with the insurgents were commenced at Stockach, and no blow was struck. Many of the peasants, especially in the Hegan, were persuaded to return to their homes, on the anderstanding that none but the old-established feudal services should be exacted. 'Everyone thought that the whole business had been properly settled and put in order.' This, however, was far from being the case : a few weeks' experience showed the villagers that nothing had been won by their rising. The majority of the nobles, believing that the entire movement had collapsed, immediately resumed their old system of oppression. Looking on their subjects not as parties in an agreement but as men conquered without a struggle, they made yet more heavy the burden which had already been found intolerable.

As a natural resalt of this display of bad faith the whole Hegau again burst into revolt, and the month of December saw an increase in the area of disaffection, accompanied by the commencement on a small scale of the deeds which usually distinguished a peasant war. The insurgents of the Black Forest, joined by some of the Klettgan people under Hans Müler, made an incursion into the Breisgan, raised the serfs there, and plundered the abbey of Bt. Rupert. Meanwhile the negotiations at Stockach showed no signe of coming to a satisfactory conclusion, though several deputations from the peasants were received and heard, and adrocates (one a doctor of the university of Tübingen) chosen to relresent them. The cause of the deadlock was simple: the nobles wished to give up as little of their power as possible, while the insurgents, after their first disappointment, were very naturally suspicious of their lords, and had made up their minds for the entire abolition of serfdom.

While this was the state of affairs in the south-west of Bwabia, in the south-east a aimilar movement began to appear. The peasants subject to the abbey of Kempten, in its broad domains esst of the lake of Constanz, had always been among the inost anfortunate of their class. Several abbots in succession had continued to encrosch upon their rights. They had done their bast to reduce 
the yeoman to a tenant, and the tenant to a serf. As early as 1492 the inhabitants had striven in an unsuccessful armed rising to win back lost privileges. Since that date more and more feudal services had been hesped on the wretched villagers. A vewly appointed abbot atterly refused all redress, and menaced petitioners with the sword of the Swabian league. Hence it was not unnatural that the people of Kempten should be attracted by the example of the Hegau and the Black Forest. Their first tumultuous assembly was on New Year's Day, $1525:^{2}$ on January 29 a great meeting formally resolved that if the Swabian league would not right them they would ' set the church bells ringing all through the Allgan and resort to force.' In a few days they were joined by the peasantry all down the valley of the Hler, including the subjects of the bishop of Augsburg and the count of Montfort. Their united forces mustered on the Luibas ander a smith named Knopf. They appear to have adopted the ides of Müller's 'Evangelical Brotherhood,' and declared everyone who would not join their society a public enemy. They then drove a stake into the ground before the door and forbade anyone to buy, sell, or hold any communication whatever with him-a course which seems to foreshadow a modern method of procedure among the peasantry of a country nearer home.

In Febraary the two areas of insurrection were connected by the revolt of the subjects of the abbeys of Ochsenhansen and Roth, and of the count of Waldburg. They numbered, if we may trust contemporary figures, ${ }^{3}$ as many as 18,000 men, and are usually referred to as the Baltringen band (Baltringer Hanfen) from the name of the village which at first formed the centre of their operations. Finally the rising of the whole of South Swabia was completed, by the accession to the insurgents of the people of the Austrian Landrogtei on the lake of Constanz and of the neighbouring territories. These were known as the Band of the Lake (See-Haufen), and were headed by a bankrupt merchant of Lindan, named Hurlewagen. The entire countryside was now divided between the five great masses of revolters - the bands of the Hegau, Black Forest, the Allgau, Baltringen, and the Lake-each of which mustered over ten thousand men.

The chiefs of the Swabian league at last recognised that it was no mere local agitation with which they had to deal, and consented to open a new series of negotiations with the pessantry on a broader base than that of the Stockach conference. They sent Neidhart, the burgomaster of Ulm, with other ambassadors of the first importance, to the camp of the Baltringen band, and asked for a fall statement of grievances and demands. Meanwhile the nobles

= Cochlmus in Baumann, p. 788.

- Schreibor des Trucheassen de. p. 538. 
everywhere withdrew into the towns, taking with them such of their more valuable goods as they could contrive to transport.

In response to the new overtures the peasants made a formil statement of their wishes. Of the documents which they submitted to the deputies of the league the famous 'Twelve Articles' ('Die gründlichen und rechten Hauptartikel aller Bauerschaft ') was the first and foremost. This declaration is of the highest importance and interest, as it furnishes us with the genuine expression of the spirit of the revolt in its earlier stage. Had we to trust for our information on this point to the vague and exaggerated language of the chroniclers, we should be far from understanding the basis on which the more moderate and clear-headed spirits among the popular leaders hoped to conclude an agreement with their masters. The 'twelve articles' was soon to become the chief manifesto of the Swabian insurrection, a position which it well deserved from its reasonable and practical character. It argues very considerable capacity in the person or persons who drew it up-we are unfortunately unable to fix with certainty on the author ${ }^{4-a n d ~ i s ~ f a r ~ f r o m ~}$ resembling the extensive scheme for the reconstruction of the whole empire which was afterwards pat forward in Franconia, or the visionary and antinomian progrumme advocated by Thomas Münzer. Stated briefly the demands of the 'twelve articles ' were:

I. That ministers should be chosen by the whole congregation, and should preach the pure gospel without human additions. If they misconducted themselves their parishioners should be empowered to remove them.

II. Only the great tithes (of wheat and other grain) as mentioned in the Old Testament should be in future exacted, and not the small tithes (of the produce of animals and the minor crops), which 'are unjust and vexatious inventions of men.' Of the proceeds one-third was to maintain the minister, the rest was to be divided between the sustentation of the church and the poor of the parish, a small reserve fund being set aside for times of war.

III. No one should any longer be held a bondman, 'for St. Paul says, "ye are bought with a price, be not ye the servants of man" 11 Cor. vii. 23). But everyone should obey in things reasonable and Christian the rulers ordained by God.'

IV. Game, fish, and fowl should be free 'as God created them,' and not preserved. They harmed the crops, and it was not right that what God had permitted to grow for man's use should be devoured by irrational oreatures.

V. The management of woods was unreasonable, as the right to all firewood was claimed by the lords. All woodland should be restored to the community, and everyone should be permitted to take as much as he

\footnotetext{
- They were trongly ascribed to Schappeler and Heuglin. Holtzwart, one of our contemporary authorities, says that the parson of Leipheim was reported to have bean the anthor.
} 
required for fuel or cerpenter's work. But this should be done under the supervision of men appointed by the community, who should prevent the excessive destruction of timber.

VI. No fendal services were to be exacted beyond those which could be proved to be of immemorial antiquity.

VI. Any work beyond these ancient services was to be voluntary and to be paid for.

VIII. Rents, which were in a majority of cases excessive, should be reduced to reasonsble amounts.

IX. All punishments should be fixed, not arbitrary, and no one should be twice punished for the same offence.

$X$. Common land on which the lords had encroached should be restored to the community.

$\mathrm{XI}$. The right of heriot should be sbolished, as being ruinous to widows and orphans.

XII. All these articles should be tested by scripture, and any which could be refuted therefrom should be null and void.

When we reflect that these demands were made by an oppressed population of serfs, labouring under strong religions excitement, and flushed by the consciousness that for the moment they had the whole country at their mercy, the moderation of the "Twelve Articles' appears astonishing. Except the method by which they were put forward-armed insurrection-there is nothing wild or revolutionary in them. It was an unhappy thing that afterwards very different manifestoes were published, which also passed for the demands of the whole people, and obscured these earlier and more reasonable requests.

One of the most striking points of the document is the manner in which things secular and religious are interwoven. The German peasant wars had from the first a strong religious colouring. Hans Behaim, the first preacher of social reform in 1476, was as much a prophet as a revolutionist. The Bruchseal insurgents of 1602 had bound themselves to say five Aves and Paternosters daily. The revolters in Würtemberg in 1513 had been encouraged by their priests, and had placed the words, ' $O$ Lord, help the righteous,' on their great banner. Now, too, though the spirit was very different, though the war-cry was no longer 'Our Lady,'s yet spiritual things were more prominent than ever. The movement of the last few years had sent the peasant to the bible, now for the first time opened to him. Accordingly the preface to the "twelve articles' was a string of texts taken from both testaments, and each clause was justified from the scriptures. There was at first no thought of maintaining that community of goods or the extermination of all adversaries was commanded in the gospel. We shall, however, see that these ideas were not unknown in a later stage of the conflict.

s As it had been at Bruchsaal in $\mathbf{1 6 0 2 .}$ 
In the first two articles, those which are devoted to religious demands, there is nothing extreme. The abolition of the 'lesser tithes' was by no means an extraordinary request. The claim of the priest to the tithe lamb or pig, and to the tenth of the crop of beans or hay, had in practice been most vexatious, and the cause of endless bickering. Meanwhile the 'great tithes,' the main source of the minister's income, were left untouched. The selection of the pastor by the congregation was a measare advocated by Zwingli, though not by Luther. In theory it was reasonable, but if put to the test at that particular moment might have led to the choice of men like Karlstadt or even Münzer. This prospect was distasteful alike to the secular and religious anthorities, and the first article was, therefore, one of those which excited the most violent opposition.

The provisions which dealt with social reform were also remarkably sensible and moderate in tone. Some of them, such as Article IX., are so obviously just that we are struck with surprise at the existence of a state of society where it was necessary to insist on them as things new and strange. Great self-restraint is shown by the paragraph which disclaims any wish to abolish ancient and customary feudel services. The fifth article, too, is noteworthy for its foresight in providing a check on the speedy destruction of forests, which would inevitably have followed their being thrown open to the depredations of all comers.

But though these demands may appear eminently rational to the intelligence of the nineteenth century, they were by no means acceptable to the south German nobles of the days of the Reformation. To minds accustomed to regard serfdom as the proper and normal state of the lower classes, the fact that the peasants were endeavouring to legislate about their own condition seemed monstrous. When they were required to make compensation for damages done by their game, to pay their labourers, to tolerate the existence of a Lutheran preacher in every village, they thought that the whole fabric of society was tottering to its fall. Was it likely that they would consent to abandon the position of lorde and masters of the rurel population, and become a mere landed aristocracy, a class preponderant bat no longer omnipotent in a community of freemen?

It is conceivable that the ruler of a considerable state might have accepted the persants' terms, with the intention of reducing the power of his nobility, just as kings of France had done in an earlier age, when they fostered the growth of 'communes.' But Swabia, even more than most districts of Germany, was split up into innumerable petty states, the dominions of counts, landgraves, and abbots. In the whole circle there was bat one important state, the dachy of Würtemberg, and this was at the time without a 
ruler. Having been confiscated in 1519 it had been placed under Austrian rule, and was now governed by local magnates, such as the counts of Fürstenberg and Helfenstein, who bore rule under the authority of the Archduke Ferdinand.

Unhappily for the credit of the aristocracy, it seems probable that the Ulm negotiations were intended to gain time rather than to lead to reforms. That the suspicion is not unjustifiable is shown by their conduct after the previous conference at Stockach. We have already seen how unpalatable the demands of the peasantry must have appeared, and how slight was the probability of their being accepted. Yet the representatives of the league did not boldly refuse to consider them, bat continued to temporise and to put off the giving of a final answer. With this end they rejected an offer of medistion made by the imperial 'Conncil of Regency.' That body, now, as always, very well-intentioned and very powerless, only able to suggest and not to command, proposed that each party should select arbiters. A prince and two cities were to be named by each, and were to decide on the measures of necessary reform. The lengue, however, would not even allow of the discussion of the scheme, for they were beginning to find themselves strong enough to resort to force. Their general George Truchsess had gradually brought together a considerable body of troops, and despite of the continuance of the negotiations proceeded to attack the peasants. He did not fall upon any of the great bands, bot routed several small parties of the Hegau insurgents. These engagements seem to have been little more than massacres; the peasants were taken by surprise, as they were aware that the Ulm conference was still in progress. Hence we find that in one conflict several hundred rebels were slain with the loss to the leaguers of only a single trooper. ${ }^{6}$

But it was not destined that the rising should be put down at this juncture. A new factor in the disturbence now appeared, who was to give the peasants some weeks of respite. Ulrich, the exiled duke of Würtemberg, had been watching the course of events from the Swiss frontier. He judged the moment favourable for the recovery of his lost principality, and is even said to have been invited to return by the bands of the Black Forest. Accordingly he set out, not for the first or the last time, ${ }^{7}$ to invade his old dominions. Leaving Bessel on 26 Feb. he hurried by a forced march into Würtemberg, having with him 100 horsemen-his own personal followers-10,000 hired Swiss infantry, and thirteen cannon. Ulrich had been anything but a model sovereign in the day of his power, but in five years his subjects had come to appre-

- See Holzwart's Rustica Soditio, p. $\theta$.

'He had already made the attempt in 1519 , and finally sacceeded in 1534 by the aid of Philip of Heser. 
hend that of two oppressive rulers the native was less unbearable than the foreigner. In the Austrian governors they had found tyrants almost as capricious and far more omnipresent than their late duke. The small towns accordingly threw open their gates to Olrich, and he was able to occupy Ballingen, Herrenberg, and Sindelfingen without striking a blow. "The populace extolled him to the skies,' says a contemporary, 'and declared that he wus the only prince worthy of the obedience of such a freedom-loving race.' Truchsess was much disturbed on hearing of the duke's incursion. $\mathrm{He}$ at once relinquished his operations against the peasants, and marched to meet the invader.

Meanwhile, on 9 March Ulrich laid siege to Stuttgart, his old capital, which was held by a garrison of the troops of the league, under the count of Helfenstein, one of the Austrian governors of the district. In spite of an energetic resistance, a bombardment of three days brought the place to the verge of surrender. But in the very moment of success the duke experienced the disastrons effect of actions which were teking place in a far distant country. On 24 Feb. Francis I of France and his Swiss allies had lost the battle of Pavis. Some three weeks later the news reached the camp before Stuttgart, together with an urgent message from the governments of the cantons that every man was wanted at home. The duke's mercenaries obeyed, and marched off in a body, so that next day the unfortunate prince found himself left with some few hundreds of men to face the approsching forces of Truchsess. Resistance was hopeless, and accordingly a rapid retreat was ordered. At Ballingen the cavalry of the league was so close behind that Ulrich abandoned his cannon, and allowed his followers to disperse. He himself, accompanied by a few horsemen, rode back to Basel in deep dejection, having experienced in twenty-five days all the vicissitudes of good and evil fortune. George Truchsess was now at liberty to turn his arms against the peasants, who for more than a fortnight had been undisputed masters of the conntry. The task before him was daily becoming more difficult: from the Black Forest and the valley of the Danube the revolt was rapidly extending northward, and had already overspread the lands on the Main and Neckar. Even more important, however, then the broadening area of insurrection was the changed spirit of the movement, which was at lest commencing to become embittered.

Up to the month of March the conduct of the peasants had been as moderate as their demands. When we consider the oppression under which they had been labouring, and the wild doctrines which had been set before them by Müner and his fellows, we may be fairly amazed at their abstention from excesses. Their behaviour had on the whole been wonderfully good. Naturally there had been much petty pillage: the fish ponds of the feudal lord had been 
drained, bis game killed, and pilfering had taken place in his deserted castle. But of graver offences there had been few : not more than two or three castles or monasteries had been burned, and these were almost without exception in the districts where there had been a conflict with the troops of the Swabian league. When the peasants found themselves in possession of the land, they set to work to negotiate with their masters, and attempted to indnce each one to sign an agreement to observe the 'Twelve Articles.' In the hour of their triumph they displayed a grotesque and lumbering hilarity rather than the ferocity that might have been expected. With the spirit of children released from fear of the rod, their leaders masqueraded in cowls and robes, and went through strange ceremonies in the character of priore or abbots. At other times they rode from village to village surrounded by the state of generals or governors. When they met a stray noble they took pleasure in addressing him with effusion as a 'Christian brother,' and sent him on his way after making him swear to observe the 'Twelve Articles.' Personal violence was as yet almost unknown. The people wandered about in great hordes, listening to preachers, exacting subscriptions to the 'Christian Brotherhood' from monusteries, and holding feasts to celebrate their newly won freedom.

A graphic picture of their behaviour is given by the monk of Irsee, whose chronicle is not the least interesting of the authorities embodied in Dr. Baumann's work. The subjects of the abbey of Irsee had risen in February, and at once commenced to put pressure on their masters, and to demand a formal ratification of the 'Twelve Articles.'

On 8 March at nine o'clock, our vassals came to the meadow of Erlesbaind with drums, fifes, spears, pikes, and every sort of weapon. Thuy were well furniehed with helmets and breastplates, and all were armed to the teeth; nevertheless, they were not very fit for war, as they were perfectly innocent of any idea of obedience to their commanders. They were but aping soldiers in spite of their fine array. ${ }^{8}$ It was a mar. vellous eight to see them, for one was bounding like a mad bull, his neighbour was yelling and tossing his arms aloft, crying, ' Ju ! Ju !' while the next would be dancing. They did not attempt to keep any rank or order, and the sight of them brought to our minds the lines of the poet:

\section{Rustica gens nulla gemss arte domabile, semper} Irrequietum animal.

Nevertheless the peesants on this occasion did the monks no harm, and went away satisfied with some documents signed and a gift of food. It was not till the heat of the struggle with the army of the league, in the ensuing April and May, that the monastery was first plundered and then burnt.

After the retreat of duke Ulrich, in the latter half of March, the

- Simias erant, etsi aurea gestarent insignia. (Chronicon Ursonense.) 
heads of the Swabian league found their troops again at their disposal. Their resolve was immedistely taken : they at once declared to the delegates of the peasants that no further negotiations would be carried on until the great bands dispersed and laid down their arms. When this was done, equitable terms should be granted. Such a conclusion was not what the insurgents had been led to expect from the previous course of the conference. They naturally refused to put themselves at the mercy of those who hed already deceived them at Stockach. On receiving their answer the league commanded Truchsess to attack the peasants nearest $\mathrm{Jlm}$, the 'Baltringen band.' Accordingly the general, who was encamped at Dangersheim, put. his troops in motion for Ulm. Now, however, he was met by an unforeseen difficulty. Duke Ulrich's invasion had called forth all the forces of the league, and especially the contingents of the towns to whom he had been a bad neighbour. The citizens had been prepared to encounter the duke, but had no burnning desire to repress the peasants, whose conduct had not as yet been such as to disgust moderate men. Accordingly a considerable part of the army met Truchsess's orders with a downright refusal to march. 'They were resolved not to stir,' said their spokesman," ' for the peasants had a just cause and were not misbehaving themselves.' Truchsess was much troubled by this declaration : he condescended to argue with the malcontents, and at last by his promises and harangues succeeded in inducing the majority of the city troops to march. The contingents of Memmingen and Constanz, however, and many of the Augsburg companies were left behind, and dispersed to their homes.

With nearly 6,000 men behind him Truchsess rode into Ulm, and passed through it to attack the Beltringen band. He found them, however, in such a good position that he shrank from a direct attack, as to reach them he would have been obliged to entangle himself in a hilly and marsby tract called 'The Alb.' To draw them down from their entrenchments he marched past their front and burnt several of the neighbouring villages, whose inhobitants were known to have joined the band. This roused the peasants to the first deeds of violence on a large scale which they had committed. Descending from their fastness they plundered and burnt the monasteries of Zweifalten, Ochsenhausen and Roggenburg, in the second of which a treasure of 7,000 gulden fell into their hands. On 2 April they made an assault on the small town of Weissenhorn, but were repulsed, in spite of the efforts of a party within the walls who made an attempt to open the gates for them. On the 4th their main body was attacked by the army of the league in front of the village of Leipheim. It was soon proved that in the open valley

- Plane nihil facturas : casuam bonam habere illos et nihil iniquum agero. (Holts. Fart.) 
the rebels could not cope with trained soldiery. We hear that many old lanzknechts were in the ranks, but if this be true they had not been able to do much to get their comrades into fighting trim. The peasante recoiled when Truchsess's artillery opened upon them, and broke into flight when his mail-clad cavalry swept down upon their ranks. A thousand were slain, four hondred drowned in attempting to swim the Danube, the rest fled to the south. The battle was followed by the first executions: on the following day the priests of Leipheim and Günzburg, both of whom had joined the insurgents, and a peasant who had led the attack on the abbey of Roggenburg, were beheaded in the presence of Truchsess.

But the spirit of the Baltringen band was not yet crushed. The survivors, reinforced by outlying parties, took post on a hillside near Wurzach, to the number of 7,000 , and again offered battle. The result of the day was even more decisive than that of the previons engagement. A vigorous attack drove the peasants back into a space where their flight was intercepted by a deep ditch, and many hundreds were cut down as they endeavoured to pass it. This blow broke up the band, and its members retarned for the most part to their homes, burning such castles and monasteries as fell in their way (13 April).

The insurgents of the Hegau and the Lake had allowed their northern neighbours to be crushed without sending a man to help them. The absence of the former body may be accounted for by the fact that they were engaged in besieging the town of Radolfzell, where Sigmund of Lüpfen and many of his brother nobles had taken refuge. It is, however, more difficult to anderstand the conduct of the band of the Lake, who, 'although they were but two dayg' march from their brethren, made no attempt to assist them. It was now their turn to face the forces of the league: Truchsess, continuing his southward march, found them 14,000 strong, entrenched at the village of Weingarten. The evening of the 16th was spent in a distant cannonade, and it appeared that the next day would see a battle. This, however, was not to be. Truchsess was apparently influenced by the news which was then arriving of the great spread of the rebellion in the north, on the Rhine, and in Franconia. The peasants moreover were more than double the number of his troops, had fortified their position, and were well provided with artillery. Instead of attacking them, he opened negotiations. It would appear that the insurgents had been discouraged by the fate of the Baltringen band, for they assumed a conciliatory attitude. In a few hours the draught of a treaty was put together, in which several of the peassnts' demands were granted, and an inquiry was promised into the whole question of serfdom. The Allgau band sent commissioners who took part in the agree- 
ment, and the majority of the insurgents of south-east Swabia returned to their homes. A portion, however, of the Kempten people, who served under a red standard which gave its name to their company, ${ }^{10}$ atill kept the field, while the scattered remnants of the Baltringen band had not entirely evacuated the district south of Ulm. These lingering sparks of insurrection Truchsess was able to disregard, when an urgent appeal drew him to andertake the suppression of the more important movement in the lands beyond the Black Forest. In those parts the revolt was now at its height. On the very day on which the treaty with the band of the Lake was signed, the celebrated massacre of Weinsberg had been perpetrated, an event which has been so frequently detailed by historians that it is generally, though erroneously, supposed to show the character of the whole war.

The pessants of the states bordering on Swabia did not rise till the insurrection in that conntry had reached its full development. Odenwald and Franconia did not become distarbed till the end of March, Thuringia and Elsass made no movement before April, and in Salzburg and the Tyrol the outbreak occurred even later.

In the lands of the Main and Neckar the first stir was caused by the news from Swabia. It may be that the emissaries of the 'Christian brotherhood' had penetrated into the district, but at any rate the 'twelve articles' were produced at the first meeting of the insurgents on $26 \mathrm{March}$, and accepted as an exposition of Franconian as well as Swabian demands. The spread of the movement was very rapid : in a fortnight the whole of the 'priests' row, the dominions of the archbishop of Mainz and the bishops of Würzburg and Bamberg, was in an uproar. The secular states fared no better, and the subjects of the margrave of Baden and the numerous counts on the Main were soon drawn into the revolt. Nowhere was there any organised force, like that which the Swabian league could show in the valley of the Danube, to offer opposition to the insurgents. There soon eppeared two great bands-the 'white' and 'black'-one of which overspread the east of the disturbed district, the other the west. In command of the white band the innkeeper George Metzler of Ballenburg was associated with the celebrated robber knight Götz of the Iron Hend, who-perhaps acting under compulsion-had joined the peasants. These colleagues wrote in a haughty strain to the archbishop of Mainz, styling themselves 'Gottfried of Berlichingen and George of Ballenburg, commanders of all who dwell between Odenwald and Neckar.'

The Black band was recruited in great measure from the subjects of the bishop of Würzburg, and was centred at Rothenburg, a small imperial town on the Tauber. At this place Karlstadt had established himself, and soon showed how intimstely his subversive

- Exercitus rubei vexilli. (Holtzwart.) 
preaching was connected with the revolution. There had been an old feud in the town-as was usual in the free communities of Germany-between the town council and a democratic faction of the unprivileged citizens. The latter espoused the cause of Karlstadt, and enabled him to carry out his ideas. It was only on March 19 that the preacher arrived in the place, but already by the 24th the images were everywhere cast down and broken, while on the 26th the priests were violently expelled from the churches when they attempted to celebrate mass. On April 8 one of Karlstadt's admirers, a certain Dr. Drechsel, preached a fiery sermon 'against emperor, kings, princes, and lords for hindering the word of God.' When the peasants were already mustering before the city gates, it was evident to what such words pointed. On the 11th an address by Karlstadt was followed by the sack of a convent. A party of the citizens there sent assurances of help to the insurgents without, while the town council was forcibly dissolved, and gave place to a committee of the democratic faction. In a fow days this body concluded a formal alliance 'for 101 years' with the peasants, and engaged to supply them with artillery and powder for an attack on Würzburg.

The Franconians were at first entirely unopposed: in their revolt. Of their ralers hardly one refused to bend before the storm; the bishop of Bamberg, the counts of Wertheim Rheineck, Henneberg and Hohenlohe agreed to all the terms which were laid before them. The bishop of Würzburg would have followed the same course but for intervening circumstances. The people of his cathedral town had allied themselves with the peasants, in order to carry out a long-cherished scheme for making the place a free city, like the neighbouring Nürnberg and Frankfurt. They did not wish that their sovereign should come to an agreement with their confederates, and contrived that the terms dictated to him should be more than ordinarily hard. The bishop, as they had foreseen, was driven to a refusal, though his means of resistance were but small. He entrusted his citadel, the Frauenberg, to Sebastian Rothenhahn, a man of whose fidelity he showed no doubt, though Sebastian when a member of the Council of Regency had proved himself a strong supporter of Lutheran views. The townspeople and peasants combined immediately laid siege to the castle, using against it the cannon which had been furnished them by the Rothenburgers. In the whole of Franconia the citadel of Wurzburg was the sole centre of opposition, and its defenders, cut off as they were from all news of the outer world, might well doubt whether the flood of rebellion was not destined to rise over the one height which still remained unsubmerged. Nevertheless the energy of the governor encouraged the garrison to hold out for a full month, until at last relief came. 
But before the investment of the Frauenberg had commenced, a deed had been done in the valley of the Neckar which wrought irreparable damage to the peasants' cause, and alienated from them the sympathy of moderate men thronghout Germany. A large party, drawn apparently from the 'White' and 'Black' bands alike, had marched towards the boundaries of Swabia, wishing-as it seems-to connect the northern and southern areas of insurrection, by opening communications with the great band of the Black Forest. The direction they took brought them into conflict with the count of Helfenstein. This nobleman, as. we have previously mentioned, was one of the Austrian governors in Würtemberg, and had distinguished himself by his successful defence of Stuttgart against Dake Ulrich. Thongh not strong enough to face the main body of the insurgents, he thought himself able to intercept the Franconian invaders. With a very scanty following he took post at Weinsberg, a little town on the Neckar which had as yet been untouched by the revolt. His energy was further displayed by the execution of some peasants of the neighbourhood who were accused of having incited their neighbours to rise. But the measure, which was intended to strike terror into the district, only led to exasperation. The moment that the Franconians appeared the whole countryside rushed to arms, and a determined assault was made on Weinsberg. The gates were thrown open by treachery from within, and Helfenstein with nineteen other knights and nobles and such of his soldiers as survived the storm were taken prisoners. The Franconian leaders Hipler and Geier bad no intention of authorising a massacre, which they knew must be prejudicial to their canse. Being no mere peasants, but politicians, and men of wide though visionary views, they had no wish to inaugurate a Jacquerie. But the local insurgents had been roused to the wildest bloodthirstiness by Helfenstein's execution of their neighbours. Before the assanlt they had sworn that they would kill 'every 'man who wore gilded spurs,' and in spite of their leaders' opposition they proceeded to fulfil the threat. At daybreak on 17 April, a certain Hans of Rohrbach led them to the prison, and brought out to them the count and his companions. It was no mere military execution which followed, but a barbarous scene worthy of savages. Its circumstances were not unlike those of the murders on Wexford bridge by the Irish rebels of 1798 . One of the prisoners, Dietrich von Weil by name, was taken to the top of the church tower, and thrown from it in his armour. The count himself was led between two ranks of pikemen, while a man named Melchior Nunnenmacher (who had formerly been his butler ") danced before him playing on a pipe, 'for the dance of death.' As Helfenstein passed,

"Pincerma, Holtswart: others give other offices to the man. For Dietrich von Weil's fate see the chroniole of Weissenhorn in Baumsnn. 
each pikeman stabbed him till he sank down dead. His young wife, who dared to intercede for him, was felled to the ground, and her infant son wounded in her arms. The remainder of the prisoners were then dragged forward and despatched in the same way as Helfenstein. Such was the famous massacre of Weinsberg, a crime which bronght a terrible retribution on all the peasants alike, though only one band had been engaged in it.

Wendel Hipler and Florian von Geier, the leaders whose orders were disregarded by the murderers, were among the few members of the higher classes who had joined the insurrection. The latter was of noble birth, ${ }^{12}$ while the former had held an official post of some importance as chancellor to the count of Hohenlohe. Hipler is celebrated for having prodaced-in conjunction with Frederick Weigant of Miltenberg-a scheme for the reconstruction of the imperial constitution which was published as the chief manifesto of the Franconian insurgents. It was a most visionary plan, full of projects for sudden and violent social changes, and oould only have been put forward during the throes of a national convulsion. It did not treat of the reform of social and religious abuses alone, as did the Swabian 'Twelve Articles,' but proposed a reconstitution of the whole state, with a special care for the interests of the peasantry. In short, just as all Sickingen's plans were coloured by the fact that he was leader of the knights, so were Hipler's by the fact that his ideal constitution was to be established by the aid of the insurgent countrymen. A sweeping confiscation of church property was, according to him, the panace for all ills. The princes and nobles were to give up, the former their taxes and tolls, the latter their fendal rights and dues. But they were not to be without compensation. The princes were to receive portions of the territory of the ecclesiastical states, the nobles of the lands of monasteries and convents. And since every rood of land in clerical hands, from the dominions of the elector of Mainz down to the holding of the smallest monastery, was to be confiscated, it was calculated that with the surplus remaining all the public expenditare of the empire could be met, and even a pittance set aside for the maintenance of the expropriated churchmen. For the emperor a tax was to be raised only once in ten years, but he was to be the sole ruler of the realm, and to him alone was allegiance to be sworn. In the unified state there was to be but one coinage and one system of weights and measures. Special care was devoted by Hipler to the parts of his scheme which dealt with the administration of justice. The peasantry bore a deep grudge against the existing courts and their Roman law. In these, as the emperor Maximilian had' said, ${ }^{13}$ 'the poor man either got no justice at all against the rich, or it was so sharp and fine-pointed

\footnotetext{
12 See the chronicle of Weissenhorn. 'A Ranke's Hist: of Roformation, vol. i.
} 
that it availed him nothing.' It was accordingly proposed that in future the citizen and peasant were to be represented by assessors in all law courts, and in the supreme court they were to muster ten rotes, as against six belonging to the princes and nobles. Doctors of Roman law were to be excluded from legal business, and were to be confined to the iniversities, where they might give advice on the theory of jurispradence. Finally, it was said, everyone was to live in brotherly love with his fellows; the clergy should be true pastors, and the princes and knights should employ their valour solely in the service of the nation.

These projects were, of course, hopelessly visionary. They insured the opposition of princes and nobles, and the bitter resistance of the clergy to the whole movement. The first were to be made merely the emperor's most powerful subjects instead of retaining their position as independent rulers, the second were to lose their cherished feudal rights, the third to be stripped of all their endowments. Unless the peasentry were strong enough to carry all before them by their unaided might, the scheme had no chance of being put into practice. Meanwhile the framers of the constitution were not likely to find the independent pablic opinion of Germany influenced in their favour by the conduct of their followers at Weinsberg. A massacre was a singular commencement for the reign of brotherly love.

From the first the conduct of the Franconian insurgents was more violent than that of their fellows in Swabia. They appear to have considered that the best way to assist their leaders' designs on church property was to destroy monasteries. Perhaps they acted on Zizca's principle that it was well to destroy the nests lest the birds should return. At any rate, the plunder and burning of abbeys and convents was begun in the first days of the rising, and the castles of the knights who bad fled or joined the garrison of Würzburg shared the same fate. Of monasteries and castles more than two hundred were ruined in the months of April and May. Those of the nobility who had acceded to the peasants' terms paid for their personal safety by submitting to constant insult and exaction. The counts of Hohenlohe were hailed as brothers and embraced by a tinker, and reminded that in future they were to consider themselves not lords but peasants. Every day some new band arrived to levy contributions 'for the common cause' from these 'richer brethren.' In short, if the leaders had expected to conciliate the upper classes by the prospect of secularisations, they found their work undone by the conduct of the mob which followed them.

In the countries to the west of Franconia the rebellion broke out in the month of April. Its greatest development was in Elsass, where 20,000 men came together and seized Zabern, the residence of 
the bishop of Strassburg. The small towns and the city of Strassburg remained nominally neutral, bat were accused of secretly assisting the peasants with arms and cannon. For a month the revolt met with no opposition whatever, and, as in the lands across the Rhine, the flames of castle and cloister shot up as the great conflagration rolled westward.

A little further to the north the elector palatine and the bishop of Speier were attacked by their subjects, and bad to trent with them on the basis of the 'Twelve Articles.' The archbishop of Mainz, whose dominions in Franconia had already passed out of his control, was in danger of losing his capital also. On 25 April the popalace rose, closed the gates, and proclaimed Mainz a free imperial city. It was several weeks before the archbishop felt himself strong enough to act. At last when he had collected 600 troopers he re-entered the town. He met with little resistance, and was able to seize and behead four popular leaders, and to reinstate himself in his former position. But in the country districts his authority was not restored till the end of June. At Trier, and even as far north as Münster, the town councils were at the same time beginning to stir against the prince-bishops who were their lords, of conrse with the object of throwing off their subjection, and becoming free cities. At Frankfurt-on-Main the corporation was attacked by the unenfranchised lower orders, but in none of these three towns did open revolts occur. The malcontents waited to see the fate of the great movement in the south, and thas escaped the fate of those who boldly committed themselves to insurrection.

In the outlying districts of the circle of the upper Rhine there was a rising in connexion with the Franconian revolt. The peasants of the spiritual principalities of Fulda and Hersfeld compelled their rulers to come to terms, and to make ample concessions in religious as well as temporal matters. In Hesse the government of the young landgrave had not been oppressive, and a strong support had been given by the authorities to the new religious doctrines. Nevertheless a slight disturbance broke out in Philip's dominions, though it was not to be compared in violence or extenit to those which raged in the neighbouring states.

But it was in Thuringia that the strangest episode of the whole war took place. The wanderings of the fanatic Münzer had brought him north, to the swull imperial town of Mühlhansen. In this place he found exactly the same state of things which Karlstadt had met at Rothenburg, and which indeed existed in most of the free cities. The town council was engaged in a losing battle with the poorer inhabitants, whose demagogic leaders were prepared to go any length in their opposition. Münzer immediately put himself at the head of the latter party ; it seems that his frantic energy drew them to follow wherever he chose to lead. The authorities 
were soon deposed and replaced by nominees of the preacher, who was himself invited to sit as their assessor. Then his frenzy burst out in the wildest extravagance. He had taught the citizens of the 'spirit' which inspired him, and he now showed them its workings. He began by measures tending to commonity of goods, and made the rich-the political party he had vanquished - maintain the poor. Next he undertook to preside in the law courts, and gave sentence 'according to his revelations' unfettered by petty technicalities of Saxon law. By this time the month of April was come, and the news of the Franconian insurrection had excited the peasantry of the surrounding districts. Feudal obligations were less oppressive and general in Thuringia than in the south, but, on the other hand, the wilder teachings of the extreme reformers had sunk deeper into the popular mind, while there existed numerous unprivileged classes-notably the semi-servile miners of the Harz district,-who longed for freedom. Münzer resolved to fan this religious and 8ocial discoutent into a flame, and to put himself at the head of the rising. The manifestoes which he issued to the Thuringian peasantry were the prodacts of a diseased mind, filled with the most frantic bloodthirstiness. He did not lay before them any political scheme, or speak of the reform of definite abuses, but preached of the estallishment of $\mathbf{a}$ 'new kingdom of righteousness,' where everything should be decided by heavenly inspiration, 'given to a second Daniel, who shall lead the people like Moses. It was no 'fabulous and honey.sweet gospel of Luther' that he brought forward, but the stern teaching of the 'spirit of inspiration.' 'I say with Christ,' said he, 'that ungodly ralers should be put to death.' 'God was abont to smite the old pots with his rod of iron,' and therefore all men should range themselves on God's side. 'Arise!' he wrote to the subjects of. the counts of Mansfeld, 'arise, and fight the battle of the Lord! The time is come, the wicked are tremıbling. But heed not the cries of the ungodly, and be pitiless. On! on! on! Let not the fire be extinguished, let not the sword grow cool from bloodshedding.' His chief fear was that the peasants might be content to exact reforms from their lords, and might shrink from following him to the end. Therefore his exhortations were heard: 'Beloved brethren, do not relent if Esau gives you fair words; gire no heed to the wailings of the ungodly. Lay Nimrod on the anvil; and let it ring lustily with your blows; cast his strong tower to the earth while it is yet day.'

Münzer's harangues were not without their effect. The rising that he desired took place, and he found himself at the head of a band of some $8,000 \mathrm{men}$, citizens of Mühlhausen, miners and peasantry. Many more gathered in troops on the hills, and waited to see the fortune of the prophet before joining him. Münzer was prepared to engage in a regular war; he had opened a cannon 
foundry at Müblhausen, and fortified the place to serve as his stronghold. But his first efforts were directed against his weakest enemies. He swooped down on all the monesteries between the Harz and the Thuringian forest, and gave them to the flames. The great work was begun, and Münzer was beside himself with joy. Everywhere his voice was heard hounding on the people to use fire and sword, while his proclamations were signed, 'Thomas Münzer with the sword of Gideon.' 'At last,' he said, 'we will pay the blasphemers back all that they have done to poor Christendom.' Having made an end of the monasteries, this dangerous madman prepared to attack the castles of the nobility. But his reign of terror was destined to last no longer than a month, and before his plans had been fally developed he met his end. While the shadow of approaching anarchy eeemed closing over the land, the good old elector Frederick of Saxony lay dying in his castle of Lochan. In despite of the surrounding confusion his end was peaceful; he had always been a kind master to his subjects, and he could meet them with a clear conscience. He did not allow his last hours to be troubled by the rebellion, 'for,' he said, ' the peasants cannot conquer unless it be by the will of God.' On 5 May he died, and was succeeded by his brother John, who was even a more zealons protector of Lutheranism than himself. The new elector had little time for mourning: before he thought of anything else it was absolutely necessary that he should suppress Münzer's outbreak.

In the same month which saw the revolt of Elsass and Tharingia there were risings in the south-east of Germany. In Bavaria the dukes had succeeded far better than their neighbours in excluding the Lutheran movement from their dominions. Bat if the duchy was quiet, on its borders the peasants of Eichstät plandered several monasteries, and besieged their bishop in his castle. They were, however, soon dispersed by troops sent to the assistance of his clerical neighbour by Duke William of Munich. ${ }^{14}$ In the Tyrol a more important movement arose. The Archduke Ferdinand, the archbishop of Salzburg, and the bishops of Trent and Brixen had all signed the reactionary agreement of Regensburg. But their subjects had other religious tendencies, and. demanded in their manifestoes that in future 'the gospel should be preached pure and plain according to the sense borne by the text.' For two months the valley of the Inn was in the hands of insurgents led by reforming zealots, while the townsfolk of Salzburg held their archbishop besieged in his citadel.

The month of April was that which saw the rebellion at its height, both in extent and in violence. From the Harz to the valley of the Adige, from Lorraine to Salzburg, the whole conntry was in an uproar, and it was only at a few isolated points that the 
movement had been checked. The successes of Truchsess and his army in the valley of the Danube, and the detersained resistance of Würzburg and a few other garrisons; seemed of no importance while the flood of rebellion continued to rise in every other quarter.

When this supreme social and religious crisis had fully developed itself, nothing conld be of more importance to Germany than the position which the recognised leaders of the Reformation might adopt. A false step might commit them either to complicity in the outrages of the peasants, or to condoning the oppression of the nobles. It is difficult to decide which of these alternative courses would have proved the more discreditable and injarious. Lackily, Lather's unswerving adherence to his principles led him to take the right decision. Now in 1525 , just as formerly during the anticlerical crusade of Sickingen, he continued to assert that the victory of the gospel was not to be won by brate force, and therefore he would not give one word of encouragement to those who made religious zeal their excuse for taking ap arms. At the very commencement of the revolt he spoke to the persants in plain terms : 'Many of their demands,' he granted, 'were founded on justice, but rebellion was the act of hesthens. Christians should endure and not fight, for the warfare of faith should not be carried on with sword and arquebus.' He therefore exhorted them, hard though the sacrifice might be, to submit to the constituted authorities. But to the nobility Luther addressed words of equal strength; their conduct he declared to be quite as sinful as that of the insurgents.

It is you [he cried] who have caused the revolt, it is your declamstion against the gospel, it is your guilty oppression of the poor of the flock. My dear lords, it is not only the peasants who have revolted from you, but God is setting himself agsinst you. The pessents are but His instruments to humble you. Think not that you can escape the punishment reserved for you; even if you conld succeed in exterminating all these rebels, God could from the stones raise up others to chastise your pride. My dear lords, calm your anger, grant reasonable conditions to these poor people as to frenzied and misled persons, appeses these commotions by gentle methods, lest they give birth to a conflagration which shall set all Germany in a flame. Remember that some of their twelve articles contain just and rational demands. ${ }^{15}$

Presently, when the news of the massacre of Weinsberg had resched him, when the excesses of Münzer were being committed at a few miles from his dwelling, the tone of Luther's exhortations became different. His tract 'Against the Plundering and Marderous Pessants' is strong even to harshness in its condemnation of actions which althongh unjustifiable were certainly not unprovoked. The reformer's zeal for the maintenance of constituted authority

"From the 'Admonition concerning the XII. Articles of the Swabian Peasants' issued arly in the spring of 1525 . 
was so strong that it overpowered all sympathy for the delusions of the class from which he himself had sprung. We must indeed remember the original bent of his character, and remind ourselves that the bands of peasants who were immediately nnder his observation were the blaspheming hordes of Münzer, or we shall be tempted to stigmatise his denunciations as truculent and unjust.

The rebels [he wrote] commit three great crimes: they rise against those to whom they have sworn allegiance, they rob and plunder castle and convent, and worst of all they cloke their crimes under the profession of the gospel. Therefore let him who can besr arms smite and slay, and meet death, if needs be, in God's service. If you neglect to shoot a mad dog, both yourself and your neighbours perish.

Such was the verdict given by Luther on the Peasants' War, a decision which unquestionably had the greatest effect in withdrawing from the rebels the sympathy of the middle classes, who looked up to the great reformer for guidance in times of doubt.

The first of all the bands of insurgents which was to meet its fate was the most mischievous, that led by Münzer. Towards the end of April, Philip of Hesse, whose own domains had been but slightly disturbed, was able to collect a considerable force, and to come to the assistance of his neighbours. He first put down the rebels of the clerical states of Fulda and Hersfeld ; next turning north he proceeded to march against the great Thuringian band. The elector John, his catholic cousin George of Saxony, and Henry of Brunswick joined the Hessians with all the followers whom they could collect. On a hillside near Frankenharasen they came apon Münzer's forces, drawn up, according to the old Hussite tactics, behind a barricade of waggons. Before commencing an attack the elector prevailed apon his colleagues to give the insurgents a last opportanity for submission. A certain Maternus Geholfen was sent as herald to them, with assurances of pardon if they would lay down their arms and disperse. But Münzer was in one of hig wildest moods : instead of returning an answer he took the unfortunate messenger and hewed him in pieces before the army. Then pointing to a rainbow which was visible at the moment, he proclaimed to his band that a miraculous sign of victory was vouchsafed them. In a few minates his lying prediction was falsified. The artillery of the princes beat upon the barricade of waggons and shattered it, ploughing through the dense ranks of insurgents who were arrayed behind. Münzer had promised his men that not one of them should fall, and the sight of the carnage around suddenly revealed to them that their prophet was a deceiver. They were already wavering when the Hessian horsemen rode forward to the attack. The peasants turned to fly, bat in a few seconds the cavalry had passed through the broken barricade and were among 
them. Exasperated by the slaughter of their envoy the victors gave no quarter, and by far the greater number of the insurgents fell in the pursuit. As many as 8,000 met their death on the spot. Münzer himself was discovered hiding in a loft. He was dragged out and taken to the camp of the princes. When questioned as to his designs he gave answers which betrayed either actual madness or the bitterest anguish of spirit. When led out to execution he was unable even to repeat the words of the creed, and seemed hardly sensible of his position.

On hearing of the death of their prophet the remainder of the Tharingian insurgents began to retarn to their homes. Mühlhausen surrendered after the faintest attempt at resistance. Only a single band remained in arms, and dared to face the elector John. He met them near Meiningen and routed them without the slightest difficulty. A few executions followed, among which was that of Strauss of Eisenach, a parish priest who had made himself prominent among the rebel leaders. The pacification of the Saxon dominions was now complete.

Five days after the battle of Frankenhausen the Alsatian revolt was suppressed. Duke Antony of Lorraine defeated the main body of the insurgents at Zabern, on which the survivors sent to demand pardon. But a fer days later they were accused of meditating a new attack, and surrounded by the forces of the duke. A mere massacre followed, in which it is said that some nine thousand rebels were slain. The whole campaign west of the Rhine is reported, we may hope with exaggeration, to have cost the lives of 17,000 peasants.

We have already mentioned that George Truchsess, at the head of the army of the Swabian league, had marched to the northwest after his treaty with the bands of the Lake and. Allgar. His line of advance brought him in contact with the insurgents of the Black Forest.' At Böblingen near the town of Sindelfingen he met and overthrew their forces. Many prisoners were taken, among whom was discovered the man Melchior Nunnenmacher, the 'piper of Weinsberg.' His execution was even more barbarous than the crime he had committed. He was fastened to a tree, while a ring of faggots was piled up at the distance of several feet from his body. When these were lighted he was slowly roasted to death, in the presence of the commander and many officers of the Swabian army. After executions had taken place and heary fines been inflicted throughout Würtemberg, the troops marched north to attack the bands of Franconia, and more especially to relieve the long-beleaguered citadel of Würzburg, where Rothenhahn was still holding out against the siege artillery and repeated assaults of the insurgents. Truchsess's route lay through Weinsberg, which be burned to the ground. A few days after, he joined the forces of 
the elector palatine and the archbishop of Trier, who had succeeded in checking the revolt on the middle Rhine, and had been lately occupied in reducing the Kraichgau to order by a series of summary hangings. The united army, now nearly ten thousand strong, marched on. Würzburg. On their way they met the 'White band,' or insurgents of the Odenwald, with which the body who had perpetrated the massacre of Weinsberg had taken refuge. Near the small town of Königshofen the peasants had posted themselves on a hillside, with no less than forty cannon disposed along their front, and with their flanks protected by two small woods. Truchsess resolved on an immediate attack : he himself with the Swabian army marched straight at the insurgents' centre, while the elector palatine turned their position by marching round one of the woods. Both movements were crowned with success: the horsemen of the league rode straight through the line of guns with no great loss, and fell on the disorderly masses behind. Just as these were recoiling the elector appeared on their flank and cut off the retreat of their left wing. In the confusion and flight which followed, an awful slaughter took place; more than 3,500 insargerits fell on the spot, and several hundreds more who threw down their arms were shot, as the granting of any quarter had been prohibited.

Two days later the 'Black band,' which had been advancing to the aid of the Odenwald army and had not yet heard of its defeat, was encountered -by -Truchsess near Engelstadt. ${ }^{16}$ Its defeat was even more bloody than that of the allied body; the victors again refused to give quarter, and 6,000 men are said to have fallen in the rout. The day had been more hotly contested than was usual ; in one part of the field a body of 600 peasants, who had established themselves in a ruined castle, held out with desperate courage all through the afternoon and evening, and were only dislodged and cut down at nightfall.

Next morning the Swabian army was drawn up and reviewed by its commander. Of the 7,200 men whom he had led from Vlm on 2 April, 5,600 were still at his disposal. In a campaign of two months, during which five ${ }^{17}$ pitched battles had been fought, Truchsess had lost only sixteen hundred men. ${ }^{18}$ The price was small when we consider that he had broken the strength of the rebellion alike in Swabia and Franconia, and had destroyed nearly twenty thousand of his unfortunate antagonists.

Now that the fighting in the valley of the Main was nearly at an end, the army of the league and the princes was joined by several new contingentg. Chief among these was that of Casimir of Hohen-

\footnotetext{
11 Not Ingolstadt, as in Ranke.

if At Leipheim, Weingarten, Boblingen, Konigshofen, and Engelstadt.

18 Holtzwart, p. 685 .
} 
zollern, margrave of Culmbach, who distingaished himself above all his fellows by his ferocious cruelty to the conquered. When once the carnage of battle was over, Truchsess had contented himself with the hanging of a comparatively small number of the ringleaders of the revolt. The atrocions execution of the "piper of Weinsberg ' was the only deed by which he can be accused of having outraged the moral feeling of the day, and in this case the provocation had nndonbtedly been great. Margrave Casimir, however, revelled in torture and mutilation. He rode from village to village supplementing the hanging or burning of the leaders by the amputation of the right hands of the led. At one place in his own dominions seventy peasants surrendered to him under a promise that their lives should be spared. Ordering them to be brought before him, he told them that he had heard how a month ago they had boasted that they should never see their master again. He was now about to verify their prediction, as they should all have their eyes put out. Accordingly the whole of the wretched men were blinded with red-hot irons, and then confined in a dungeon, where the greater part perished from the festering of their untended wounds.

On 6 June the allied army appesred under the walls of Würzburg and relieved the long-besieged citadel. ${ }^{19}$ The town surrendered after a faint show of resistance, and a mixed multitude of five or six thousand peasants and citizens laid down their arms in the market-place. From among them their muster, the bishop, picked out sixty-two, who were beheaded: Florian von Gejer, however, who had been their chief commander, seems to have escaped. Götz of Berlichingen, the other noble who had been implicated in the revolt, and had held command in the 'White band,' was less fortanate. In spite of his protestations that he had only acted under compulsion, he was thrown into prison and held in strict confinement.

After the relief of Würzburg the princes marched to reduce the eastern parts of Franconia. There was no longer any heart left in the insurgents ; Bamberg, Rothenburg, and Schweinfurt surrendered at the first summons, and gave up their leaders for execation, besides paying fines of from two to six thousand gulden. The last band of peasants which held together was surprised and cut to pieces by Margrave Casimir near Dünkelspiel, and by the end of June the whole country was reduced to order. Its condition, however, was fearful : beside the ruins of sixty burnt castles and abbeys lay those of twice as many sacked villages; corpses swung on gallows at every cross-road, and the unburied bodies threatened to breed a pestilence round the battlefields of Engelstadt and Königshofen.

\footnotetext{
11 It was none tho anon, as the besiegers had opened a breach 25 foet wide in one place, and had mined the wall and were ready to throw down 150 feet of it in another
} 
'The neck of the rebellion had now been broken; the remainder of the war was little more than the dying struggle of the isolated and outlying limbs. It was only in a few districts that the peasants remained in arms, and against these the whole force of the conquerors could be concentrated. The elector palatine and the archbishop of Trier stamped out the last sparks of insurrection on the lower Main and the banks of the Rhine. The army of the Swabian league marched to subdue the revolt which lingered in the country round Kempten. There the 'band of the red flag' had reigned unresisted since the end of April. They had committed the wildest devastations, barning every castle and convent in the Allgau. At Babenhausen, where they met with resistance, they massacred the acanty garrison to a man. Hearing that the arms of the league were now to be turned against them, they concentrated to the number of fourteen or fifteen thousand in a fortified position behind the river Luibas. Before this appeared on 19 July not only Truchsess and the troops he had led from Franconia, but the famous old general, George of Frundaberg, who bad lately returned from Italy, and had been placed at the head of a small reserve army, which the league had raised during the absence in the north of its main force. For a day the peasants held their ground against the cannon which played upon them from the farther bank of the river. On the next morning, however, they were found to have disappeared. We are told that two of their leaders had been bought over by Frundsberg. These men, if report spoke aright, proposed a night attack on the Swabian camp, and led their followers by the wrong path to two isolated spots at a distance from their fortified position. At daybreak the peasants found themselves separated and misled; instead of attempting to regain their stronghold, they retreated to the hills. After a few days they began to grow short of provisions, gave up their chiefs to Truchsess, and surrendered at discretion. Twenty-four of the prisoners were beheaded the next day : the rest were dismissed to their homes. ${ }^{20}$ About the same time the bend of the Hegan, which had been occupied for the last two months in besieging the town of Radolfzell, was dispersed by the count of Werdenberg.

Of all the insurgents, who in April had appeared to be masters of half Germany, only those of the Tyrol remained unsubdued. Their reduction did not take place till the spring of 1526. This long immunity which they enjoyed was due to a series of negotiations which they carried on with Ferdinand of Austria. The archduke, unlike most German princes, sew his way to making profit out of the rebellion. The subjects of his clerical neighbours the archbishop of Salzburg and the bishops of Trient and Brixen offered to accept him as their sovereign, if he would grant them

* Geyer's Handlung des Burds wider dio Bauorn, p. 746. 
certain terms, modelled on the 'Twelve Articles.' Catholic though he was, Ferdinand showed no scruple in consenting to the robbery of spiritual princes. He entered into a discussion with the rebels, and would undoubtedly have secularised the bishoprics had he not met with opposition. The Swabian league, however, and the dukes of Bavaria interfered, and Ferdinand had no wish to come into conflict with them. He therefore abandoned the peasants. Left to themselves the mountaineers made a gallant stand. The first attack of the Swabian troops on the Salzburg band was defeated with the loss of 1,000 men, by far the heaviest suffered by the victorious party in the whole of the peasant war. The second assault, made by increased forces, guided bo deserters, and headed by the experienced George of Frundsberg, was more successful. The rebels were dislodged from their fastnesses, and compelled to disperse. Thus the last embers of the great conflagration of $\mathbf{1 5 2 5}$ had at last been stamped out.

The end of the period of actual conflict in south Germany was by no means synchronous with that of the period of punishment. On the districts already most exhausted by loss of life and destruction of material resources the penalty fell heaviest; for nine months after the fighting had ceased large bodies of the troops of the league were kept at free quarters in the towns and villages which had been the centres of revolt. By their aid rebel leaders who had for the moment escaped were continually being hunted down. Many of these fagitives were apprehended, and their executions prolonged a reign of terror for several months. Others fled to distant lands, and several are said to have been recognised twenty years later serving in the ranks of the Turkish invaders of Hungary. It is computed that in all no less than 2,000 persons were hanged or beheaded between the months of April and September. 'There was not a single noble,' writes a contemporary chronicler, 'who did not execute several peasants, and fine or imprison many more.' The exactions on the ravaged districts were often enough to retard their recovery for years; not only were heavy poll taxes of four or five florins laid upon the villagers, bat the corvees and requisitions for men, carts and horses were unending. The general principle was that the harm done should be repaired by those who had wrought it, and therefore devastated castles and monasteries, whose building had been the work of centuries, were now to be reconstructed by forced labour in two or three years. Truchsess bimself, pitiless as he had shown himself during the conflict, was an exception to the general rale, when he told his vassals that both he and they had suffered sufficiently from the war, and that no farther burden should be laid on them.

C. W. C. Oras. 